UNDERGRADUATE RESEARCH IN NATURAL AND CLINICAL SCIENCE AND TECHNOLOGY (URNCST) JOURNAL Read more URNCST Journal articles and submit your own today at: https://www.urncst.com

\title{
siRNA Dynamic PolyConjugates for the Targeting of Hepatocyte HAMP Genes as Potential Treatment for Anemia of Inflammation: A Research Protocol
}

Isabel O. Bae, BHSc (Honours) Student [1]*, Grace C. Cheung, BHSc (Honours) Student [1], Chelsea Kim, BHSc (Honours) Student [1], Joyce X. Qiu, BHSc (Honours) Student [1], Najifah Tasnim, BHSc (Honours) Student [1], Tiffany Yu, BHSc (Honours) Student [1], Andy Zhu, BHSc (Honours) Student [1]

[1] Faculty of Health Sciences, McMaster University, Hamilton, Ontario, Canada L8S 4L8

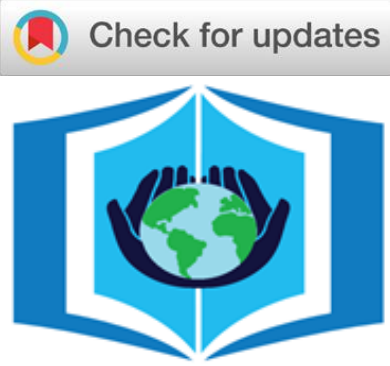

URNCST Journal

"Research in Earnest"

*Corresponding Author: $\underline{\text { baei@mcmaster.ca }}$

\begin{abstract}
Introduction: Anemia of inflammation (AI) is a condition caused by iron sequestration from invading pathogens, which is primarily caused by hepcidin upregulation. This results in low serum iron levels. The objective of this research protocol is to evaluate the potential of small interfering RNA (siRNA) Dynamic PolyConjugates (DPCs) in decreasing hepatic hepcidin expression for AI treatment.

Methods: DPCs carrying Hepcidin Antimicrobial Peptide (HAMP) gene siRNA will be synthesized and injected into the tail veins of AI-induced mice on a standardized low-iron diet. Various experiments will then be conducted to verify that siRNA DPCs specifically target hepatocytes without causing significant toxicity. To evaluate the treatment's efficacy, HAMP mRNA and serum iron levels will be measured using Reverse Transcription Quantitative Real- time Polymerase Chain Reaction (RT-qPCR) and a common calorimeter method, respectively. These measurements will determine the potential of siRNA to silence hepatic hepcidin expression and its resulting ability to increase serum iron levels.

Results: It is anticipated that successful targeting of siRNA DPCs to hepatocytes will be confirmed through immunofluorescence and that toxicity levels induced by the treatment will be statistically insignificant. Moreover, we expect lower HAMP mRNA levels and thus higher serum iron concentrations in the experimental group compared to the control.

Discussion: Hepatocyte-specific delivery of the siRNA DPC with minimal toxicity and effective silencing of the HAMP gene would deem this delivery vehicle to be a notable candidate in treating AI compared to other current conventional treatments. Certain limitations include confounding variables and potential toxicity, which should be further considered.

Conclusion: Future implications of this study include human testing of siRNA DPC administration in AI patients as well as using DPCs conjugated to other siRNAs in the potential treatment of other gene-related pathologies associated with abnormal upregulation of specific proteins.
\end{abstract}

Keywords: anemia of inflammation; anemia; siRNA DPC; siRNA; hepcidin; hepatocyte; HAMP gene; nanoparticles; nanotechnology

\section{Introduction}

Anemia of Inflammation

$\mathrm{AI}$ is the second most prevalent form of anemia and is a condition of insufficient iron in circulation, often occurring in individuals with pre-existing inflammatory conditions, such as cancer, infections and autoimmune disorders [1-5]. It is predominantly caused by hepcidin dysregulation where hepcidin is a hormone regulator of iron homeostasis expressed by the HAMP gene in the liver $[1,4,6,7]$. Hepcidin is released into circulation to bind to ferroportin (FPN) before undergoing endocytosis into hepatocytes, duodenal enterocytes, and macrophages after which it can degrade FPN and limit iron export into circulation. [1,2,6-8]. Excessive hepcidin release results in iron retention in enterocytes, macrophages, and hepatocytes and blocked dietary iron absorption in the duodenum [4,5,7,9-11]. AI's prevalence in inflammatory conditions is due to the fact that inflammation triggers the release of cytokines, some of which are potent inducers of hepcidin $[4,7-10,12]$.

Given this, experimental therapies that target the hepcidin-FPN axis are a promising avenue to explore $[13,14]$. Current management therapies for AI patients, such as erythropoiesis stimulating agents, iron supplements and blood transfusions, merely alleviate symptoms and do not sufficiently target hepcidin $[4,13,15,16]$. As hepatocytes are critical parenchymal cells of the liver with a notable capacity to store iron, reducing hepcidin levels among this 
UNDERGRADUATE RESEARCH IN NATURAL AND CLINICAL SCIENCE AND TECHNOLOGY (URNCST) JOURNAL Read more URNCST Journal articles and submit your own today at: https://www.urncst.com

particular population of cells and consequently elevating their FPN density would be a prominent area of interest for AI patients $[1,2,6,17]$. As such, this proposal aims to use a novel siRNA DPC approach to silence the HAMP gene as a potential treatment for AI.

siRNA and Dynamic PolyConjugate Technology

siRNA DPC technology has previously accomplished successful targeting of siRNA to hepatocytes and consequent gene silencing in recent studies by Rozema et al [18]. The siRNA DPC comprises two essential parts: the siRNA, which is a double-stranded RNA (dsRNA) that can silence the expression of specific genes based on its sequence and the DPC, which serves as a delivery vehicle [18].

Key components of the DPC vehicle include an endosomolytic polymer termed polyvinyl ether (PBAVE), composed of butyl and amino vinyl ethers to which siRNA, as well as polyethylene glycol (PEG) and $\mathrm{N}$-acetylgalactosamine (NAG) groups are conjugated [18]. PBAVE is an endosomolytic agent previously developed by Wakefield et al. that allows for endosomal disruption-a key step during siRNA delivery [19,20]. Avoiding nonspecific interactions between the siRNA DPC and circulating proteins is critical for the siRNA to remain attached to the complex when the DPC is enroute to the liver [18]. This avoidance is ensured by PEG, which serves as a shielding agent in the DPC $[18,21]$. Meanwhile, NAG is the principal molecule modulating hepatocyte-specific delivery [18,21]. It is a galactose-derived agonist whose asialoglycoprotein receptor (ASGPr) is heavily expressed on hepatocytes $[18,21]$. This agonist-receptor recognition drives specific receptor-mediated endocytosis of the siRNA DPC complex into hepatocytes, rather than cells lacking ASGPr expression such as Kupffer macrophages which induce toxicity upon activation by the foreign siRNA $[18,21]$.

Other preeminent features of siRNA DPCs include their proven ability to induce less toxicity despite being synthetic [18]. Specific delivery of siRNA to hepatocytes by NAG prevents uptake into Kupffer cells and subsequent toxicity $[18,22]$. Furthermore, the selective activation of the siRNA DPC ensures that the siRNA is not released until cell entry [18]. This prevents the vehicle from deleteriously interacting with other membranes it encounters prior to hepatic endocytosis [18]. This is implemented by acidlabile maleamate bonds, which mask PBAVE's endosomolytic activity until brought into the cell via endocytosis [18]. Under physiological conditions, this polyconjugate complex is negatively charged, soluble and non-aggregating, making it an ideal delivery vehicle $[18,19,23]$. Additionally, the size of this siRNA DPC is significantly smaller than other commonly used siRNA nanoparticles, reducing the risk of liver toxicity and allowing for more flexible specific targeting [18,23]. Collectively, these factors deem this delivery mechanism a suitable candidate for our protocol $[18,23]$.

\section{Objectives}

The objective of this experiment is to evaluate the potential of siRNA DPC in decreasing hepcidin expression for the treatment of AI. In our proposed experiment, DPCs containing siRNA targeting the HAMP gene will be synthesized and injected into murine models of AI. Various experiments will then be conducted to verify that siRNA DPCs specifically target hepatocytes without causing significant toxicity. To assess the effectiveness of the treatment, two variables will be measured within this experiment: HAMP mRNA and serum iron levels. These measurements will gauge the inhibitory impact of siRNA on hepatic hepcidin expression and its corresponding ability to increase serum iron levels to treat AI [18].

\section{Methods \\ In vivo Preparation}

The experiment will use murine models of AI with C57BL/6J mice, following the protocol described by Kim et al [24]. This procedure will exclusively use male mice to avoid sex-related discrepancies in iron homeostasis and hepcidin production that may introduce confounding variables in the experiment [24]. All mice will be fed a standard chow (270 ppm iron) for 6 weeks of age, after which they will be maintained on a low iron diet $(50 \mathrm{ppm}$ iron) for 2 weeks [24]. At 8 weeks of age, sixty experimental mice will be intraperitoneally injected with $5 \times 10^{8}$ particles of heat-killed Brucella abortus bacteria to induce AI [24]. Six control mice will be injected intraperitoneally with saline [24]. Both groups will be maintained on this low iron diet. This is done because standard chow elevates hepcidin levels and desensitizes the mice's response to bacterial inflammation, producing a suboptimal AI model [24]. To confirm that AI was induced, hemoglobin and iron levels will be measured and compared between experimental and control groups [24]. Figure 1 outlines the respective allocation of mice into the various experiments involved in this protocol. 
UNDERGRADUATE RESEARCH IN NATURAL AND CLINICAL SCIENCE AND TECHNOLOGY (URNCST) JOURNAL Read more URNCST Journal articles and submit your own today at: https://www.urncst.com

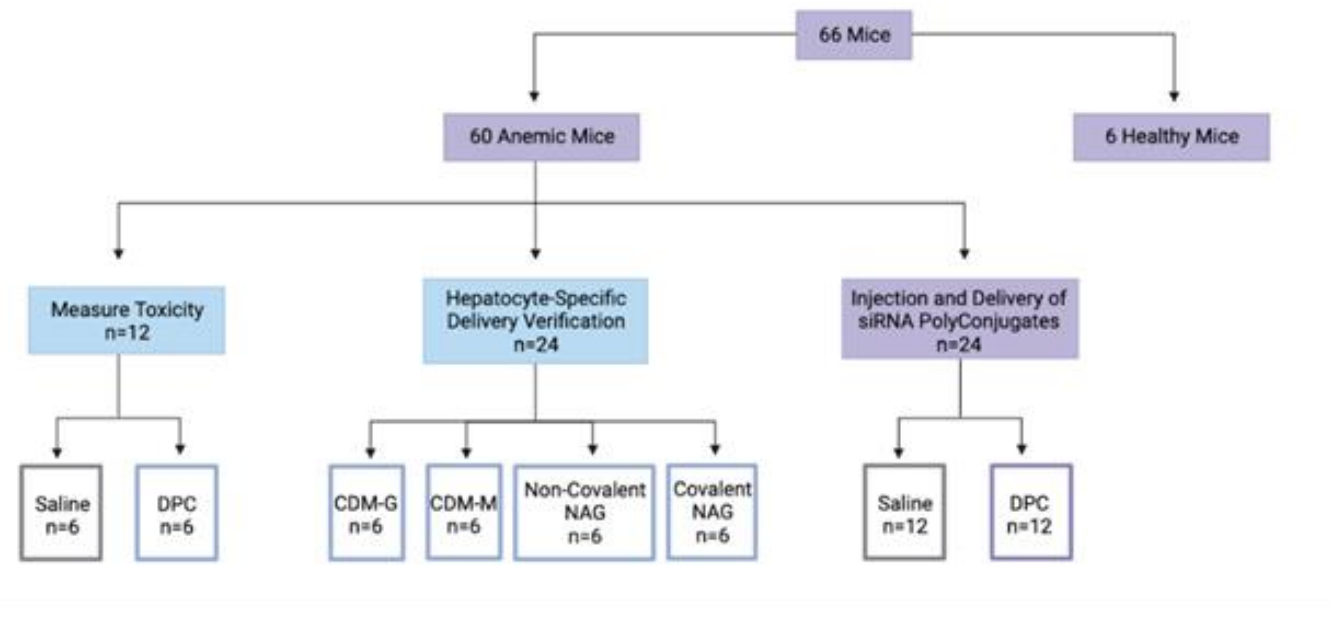

Figure 1. Flowchart depicting and summarizing our proposed mechanism. This figure was created using Biorender.com.

\section{Synthesis of PolyConjugate}

The siRNA DPC will be used to deliver siRNA to hepatocytes in vivo (Figure 2). Synthesis of this complex will follow the protocols described by Rozema et al [18]. To construct the polyconjugate, we will first need to link the HAMP gene siRNA to the backbone of the PBAVE polymer through a reversible disulfide linkage [18]. This disulfide linkage will prevent the displacement of the siRNA from the polymer while traveling to hepatocytes [18]. However, a limitation of this conjugation reaction is its yield of $70-90 \%$ [18]. This shortage in the desired product will be accounted for by utilizing higher reactant concentrations during this reaction [18].

Subsequently, we will use a bifunctional maleamate linkage to reversibly attach PEG and NAG to PBAVE [18]. This is achieved by using carboxy dimethylmaleic anhydride (CDM) derivatives as a linkage $[18,19]$. These derivatives additionally mask the polymer's positively charged amines and hydrophobic behaviour to form acidlabile maleamate groups, which prevent the release of PEG, NAG and siRNA in circulation [19].

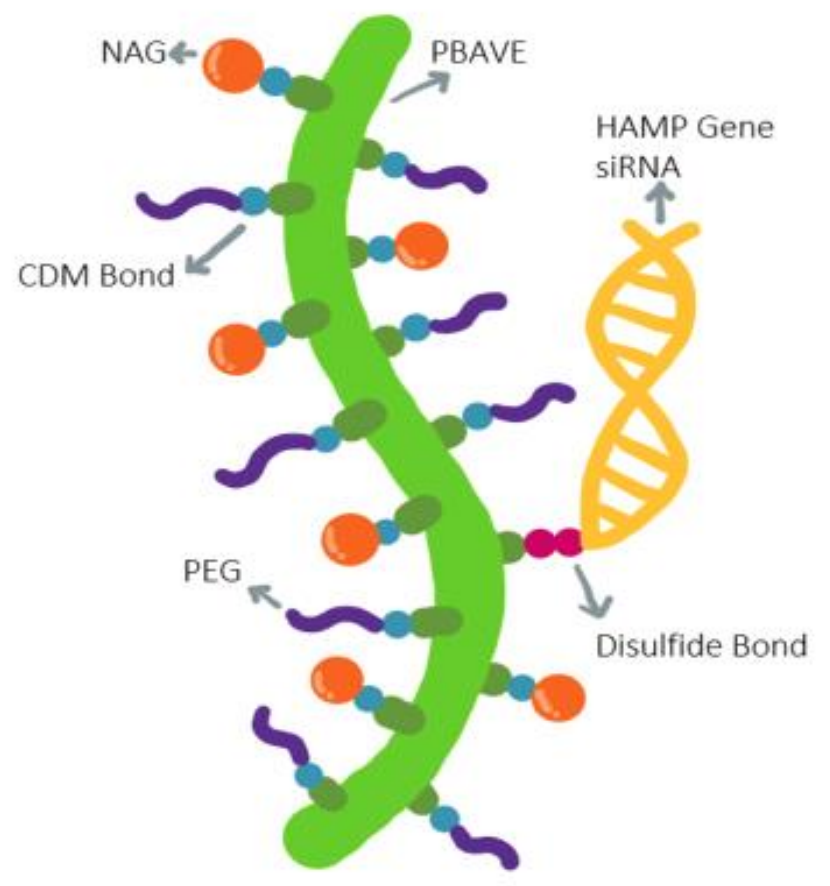

Figure 2. Structure of siRNA DPC. This figure was created using Microsoft OneNote. 
UNDERGRADUATE RESEARCH IN NATURAL AND CLINICAL SCIENCE AND TECHNOLOGY (URNCST) JOURNAL Read more URNCST Journal articles and submit your own today at: https://www.urncst.com

\section{Measuring Toxicity}

A crucial component in the delivery of siRNA DPCs to hepatocytes is ensuring that this mechanism does not counterintuitively induce toxicity in the body [18]. Although the small size of DPCs have been shown to reduce liver toxicity, the synthetic nature of DPCs may have harmful effects on the body contrary to natural nanoparticles [18]. Hence, the potential toxicity of polyconjugates will be tested by measuring serum levels of toxicity-associated proteins, enzymes and cytokines in the liver in anemic mice [18].

Following the procedures outlined by Rozema et al., the HAMP siRNA DPCs or saline will first be evenly administered via intravenous injection into the tail veins of twelve anemic mice [18]. Six will receive saline, while the other six will receive the HAMP siRNA DPCs for comparison. To measure protein levels, liver serum will be collected at various time intervals after injection [18]. Gel electrophoresis will then be used to separate and transfer serum proteins to a polyvinylidene difluoride membrane where they will be incubated and diluted with primary rabbit polyclonal antibodies [18]. This will be followed by the addition of a secondary goat antibody that is attached to horseradish peroxidase to allow detection of the respective proteins [18]. Binding of these antibodies will be assessed using an enhanced chemiluminescent detection kit to determine toxicity levels [18]. High levels of specific proteins such as aminotransferases, alkaline phosphatase (ALP) and $\gamma$-glutamyl transferase $(\gamma \mathrm{GT})$ in the serum of the liver will act as biomarkers for liver injury caused by the siRNA polyconjugates $[18,25]$. Additionally, a sandwich enzyme-linked immunosorbent assay (ELISA) will be used to analyze serum levels of the cytokines, tumour necrosis factor alpha (TNF- $\alpha$ ), interleukin-6 (IL-6), and interferon alpha (IFN- $\alpha$ ) in accordance with R\&D Systems and PBL Biomedical protocol [18]. Finally, serum levels of enzymes released upon liver damage such as alanine transaminase (ALT) and aspartate aminotransferase (AST) will be measured for each individual mouse [18].

\section{Verifying Hepatocyte-Specific Delivery}

Targeted delivery of the siRNA vehicle must first be confirmed through confocal microscopy procedures outlined by Rozema et al [18]. Specifically, this study used 21-mer dsDNA, a siRNA mimic, to simulate siRNApolyconjugate delivery [18]. This was done to confirm the dsDNA-polyconjugate's targeted delivery to mice hepatocytes before testing with the study's respective siRNA [18]. A replication of this experiment with HAMP siRNA will be conducted to account for possible differences and the effects of HAMP siRNA on the polyconjugate's delivery.

This confocal microscopy procedure will comprise fluorescent labelling where the siRNAs, nuclei and cell membranes will be labelled with red Cy3, blue ToPro-3 and green Alexa 488 phalloidin dyes, respectively [18]. The
siRNA will first be stained and conjugated to a fluorophore before it is intravenously injected into mice via their tail veins [18]. One hour post-injection, the nuclei and cell outlines will be isolated from the murine liver and counterstained for enhanced visualization and differentiation between hepatocytes and nonparenchymal cells [18]. To construct the confocal pictures, 11 optical images, each 0.4 $\mu \mathrm{m}$, will be combined and layered to form a flattened projection that represents the fluorescence signals from a liver section measuring $4 \mu \mathrm{m}$ in thickness [18].

This specific experiment will involve two control and two experimental groups, each group comprising six anemic mice [18]. The control groups will use CDMglucose and CDM-mannose instead of CDM-NAG, while the experimental groups will use covalently and noncovalently attached CDM-NAG [18]. For the experimental groups, CDM-NAG will be expected to have preferential accumulation in hepatocytes due to hepatic ASGPr expression, but only when NAG is covalently bound to CDM [18]. Rozema et al. previously demonstrated that noncovalent complexing of NAG causes its immediate release upon injection into circulation [18]. As targeted delivery relies on NAG, immediate detachment of NAG from the polymer will significantly reduce hepatocytemediated uptake [18]. This will be further verified with HAMP siRNA bound to CDM-NAG through both covalent and ionic bonds [18].

\section{Injection and Delivery of siRNA PolyConjugates}

Previous findings have proven that the amount of the siRNA attached to the DPC is a limiting factor for the repression of a target gene, such as the HAMP gene, while the amount of endosomolytic polymer has a minimal effect [18]. Thus, our experiment will only alter the amount of siRNA conjugated to the polymer. Specifically, varying concentrations of siRNA through serial dilutions will be injected into twelve experimental mice to produce a doseresponse curve [18]. In each dilution, the amount of siRNA on each individual polymer will decrease, while the total amount of polymer remains constant [18]. This will allow us to investigate the effects of varying siRNA concentrations on hepatic HAMP gene expression without the polymer as a possible confounding variable. Ideally, injection of the serial dilutions of siRNA polyconjugates should be inversely proportional to hepatic HAMP gene expression.

In this experiment, we will utilize twenty-four anemic mice in total - twelve will receive siRNA DPC injections and the other twelve will receive saline as a control. HAMP mRNA and serum iron levels will then be measured to assess the treatment's efficacy using RT-qPCR and a common calorimeter method, respectively.

\section{HAMP mRNA Levels}

The measurement of HAMP mRNA levels to determine the effect of siRNA doses will be performed with harvested mouse livers through RT-qPCR methodology, two days 
UNDERGRADUATE RESEARCH IN NATURAL AND CLINICAL SCIENCE AND TECHNOLOGY (URNCST) JOURNAL Read more URNCST Journal articles and submit your own today at: https://www.urncst.com

after siRNA injection [18]. Specific steps of the particular RT-qPCR procedure are indicated by Wong et al., with the general steps comprising RNA isolation and characterization, synthesis of complementary DNA as well as polymerase chain reaction data acquisition, normalization and data analysis [26]. This study will adhere to the well-established steps of RT-qPCR as indicated in other articles, namely Song et al. and Gulec et al [27,28]. First, the RNA from the liver will be isolated by a Trizol reagent $[27,28]$. cDNA is then synthesized from the RNA [26-28]. Afterwards, the cDNA will be amplified (fluoresced) for the HAMP gene using SYBR-Green dye $[27,28]$. Once the quality of the sample has been approved via normalization, final data analysis can occur to measure the mRNA levels before a comparison can be made between the HAMP mRNA levels of the control group to the experimental group $[18,29,30]$. Here, the extent to which siRNA can potentially impact hepatocyte hepcidin expression can be determined [18]. Once the quality of the sample has been approved via normalization, a final data analysis can occur to measure the mRNA levels before a comparison can be made between the HAMP mRNA levels of the control group to the experimental group [18,29,30].

\section{$\underline{\text { Serum Iron Levels }}$}

To determine whether siRNA can help treat AI by increasing circulating iron, serum iron levels will be measured. As described by Young and Hicks, serum nonheme iron levels will be determined using a common calorimeter method that uses the AutoAnalyzer system [31]. This method allows for the automatic measurements of serum iron and iron binding capacity and eliminates the need for iron-free glassware. As diet can cause fluctuations in serum iron, we will measure serum iron levels each morning of the experiment for two weeks before the mice are fed to provide a standardized measurement of iron levels [32].

\section{Results}

In the preparation of AI-induced mice, it is expected that mice receiving Brucella abortus bacteria will have reduced hemoglobin and iron levels compared to those receiving saline, confirming AI diagnosis. This is supported as our procedures followed that of Kim et al. which presented such data and successfully induced murine AI.

Furthermore, we will verify successful synthesis of the siRNA DPC through confocal microscopy. Proper CDM linkage of the PEG and NAG strands to PBAVE and appropriate siRNA attachment through disulfide bonds is expected [18].

In terms of measuring toxicity, low and normal levels of serum protein biomarkers of liver toxicity, AST and ALT (8-48 U/L and 7-55 U/L respectively) in mice receiving siRNA DPCs will be expected. As these molecules are released upon liver damage, higher levels compared to the control would indicate liver toxicity, which we do not expect in this experiment given the anticipated ability of siRNA DPCs to specifically target hepatocytes and thus avoid Kupffer immune cell uptake [18]. Further, slight increases in enzyme or cytokine levels in siRNA DPC mice compared to the controls will be deemed insignificant if $\mathrm{p}>0.05$ [18].

Red dye will be covalently attached to the polyconjugate through a disulfide linkage for visualization to confirm hepatocyte-specific delivery. The red dye is expected to be observed within the blue-stained nuclei of hepatocytes in the final confocal images after layering, confirming the polyconjugate's targeted delivery [18]. In the case of CDM-glucose, this control will represent nonspecific delivery, as it lacks NAG and thus cannot bind to ASGPrs expressed on hepatocytes to aid in targeted delivery [18]. Consequently, the resulting confocal images will serve as a reference point for comparison with results using CDM-NAG [18]. Similarly, CDM-mannose will also serve as a control lacking hepatocyte-specific delivery [18]. Mannose is a C-2 epimer of glucose which acts as a ligand binding to mannose receptors [33]. Experimentation with CDM-mannose will confirm the mechanism of ligand attachments mediating the targeted uptake of polyconjugates into specific cells expressing the ligand's respective receptor [18]. Thus, CDM-glucose is expected to have non-specific delivery with no particular accumulation of red dye while CDM-mannose is expected to have more red dye observed in parenchymal liver cells such as sinusoidal, endothelial, and Kupffer cells, which all express mannose receptors. To differentiate these cells from hepatocytes that are the target cells, antibodies can be used. This would be done by first adding primary antibodies that specifically bind to the NAG receptor that is specifically found in the hepatocytes. Then, secondary antibodies that will bind to these primary antibodies and undergo reactions to generate recordable light for detection of the hepatocytes. Conversely, the experimental groups of CDM-NAG will be expected to have preferential red dye accumulation in hepatocytes due to hepatic ASGPr expression, but only when NAG is covalently bound to CDM. This is supported by Rozema et al. who previously demonstrated that noncovalent, electrostatic complexing of NAG causes its immediate release upon injection into circulation [18]. Specifically, this occurred in the presence of serum or physiological salt concentrations but not within the presence of charge-dense polycations, which help maintain the ionic bonds of CDM-NAG [18]. As the targeted delivery relies on the NAG ligand, immediate detachment of NAG from the polymer will significantly reduce hepatocyte-mediated uptake [18].

It is further expected that in the proposed animal studies, injection of the serial dilutions of siRNA polyconjugates will be inversely proportional to hepatic HAMP gene expression [18]. Specifically, we expect lower HAMP mRNA levels measured by RT-qPCR technology and greater serum iron levels following the siRNA injection 
UNDERGRADUATE RESEARCH IN NATURAL AND CLINICAL SCIENCE AND TECHNOLOGY (URNCST) JOURNAL Read more URNCST Journal articles and submit your own today at: $\underline{\text { https://www.urncst.com }}$

as a result of mRNA degradation by the siRNA and therefore enhanced iron export. The expected timeline for these measurements will be over a duration of two weeks.

\section{Discussion}

Analysis and interpretation of the results will be performed to assess the efficacy, viability and potential toxicity of the suggested siRNA DPC treatment for AI. The measurement of mRNA and serum iron levels will reveal this treatment's overall viability. Decreased HAMP gene levels leading to increased serum iron levels from siRNA DPCs would indicate that the hepatic targeting of HAMP siRNA can alleviate AI symptoms. To ensure the consistency and reliability of the treatment, further studies should focus on the reproducibility of such results.

As this experiment will exclusively use male mice, a definite limitation is that the results may be less representative of the female population. Experimentation with female subjects may further verify the potential of siRNA DPC as a treatment of AI. Additionally, repetitive serum blood testing may present another limitation, as such procedures contribute to blood loss and consequent iron loss [24]. These tests may aggravate anemia symptoms in the short-term and counteract the effects of the siRNA DPC when subsequent measurements of iron levels are performed [24]. This will be considered when interpreting our results.

Furthermore, potential toxicity issues may arise from the treatment itself. Specifically, synthetic polymers, such as PBAVE, have the potential to induce toxicity through Kupffer cell activation [18]. Although these toxic effects have previously been shown to be reduced through hepatocyte-specific delivery, methods to further avoid these macrophages would be ideal [18]. Future studies may wish to further test, reconstruct and adjust the amount of siRNA DPC used to minimize toxicity levels. Specifically, a polymer natural to mice that resembles PBAVE may be alternatively used to prevent toxicity, thereby mitigating this limitation. This is due to the fact that natural polymers are not considered as foreign antigens unlike those that are synthetically-derived.

Since the aforementioned experiments were conducted in mice models, it is important to note the potential implications and differences these results would have in human models. Mice models are often used in many experimental designs as there are many genetic and physiological similarities between the two species. However, due to evolution and natural selection, alongside epigenetic changes, there may be many variations in the genomes of the two species that may result in potential differences in response to the experiments in humans [34]. Additionally, in this article, the mice were on a particular diet to ensure optimal conditions were met for this study and to ensure diet is not a confounding factor. In humans, diet would play a role as a major confounding variable as depending on epigenetics, geography or ethnicity, humans eat varying diets that may cause differences in the results seen. For example, some diets are more rich in heme-iron while others are rich in non-heme iron whereas others are not iron rich at all. Moreover, certain human populations such as the South Asian population have greater prevalence of iron-related disorders such as iron-deficient anemia which would also cause differences in results seen in human models [35]. Overall, although mice models are an appropriate starting point, future studies should focus on applying the experiments to clinical trials to identify other potential confounding variables and determine differences in physiology and genetics that cause variability in results to evaluate the effectiveness of this treatment on humans

Despite these aforementioned limitations, the advantages of research into siRNA DPC as a viable treatment for $\mathrm{AI}$ is expected to outweigh its disadvantages.

\section{Conclusions}

This research protocol aims to present and evaluate a new treatment for AI, while expanding the foundation for research on the novel therapy of siRNA DPCs. By directly targeting HAMP, these proposed siRNA DPCs are expected to lower dysregulated hepcidin levels and thus account for all the factors that contribute to hepcidin upregulation in AI such as the aforementioned cytokines. Since siRNA is short acting, this sharp reduction in HAMP will alleviate symptoms with near-maximal silencing for 5-7 days [36]. This deems it more effective than conventional treatments that merely alleviate symptoms. Therefore, findings from this protocol would be especially relevant to patients whose AI stems from an untreatable, inflammatory chronic disease that induces hepcidin dysregulation. All patients would be screened for hepcidin expression levels before potential treatment. For prolonged effects, continued DPC treatment would be required. Future studies should investigate the administration of the siRNA DPC in clinical trials and may wish to build upon this approach by using other types of siRNAs and directing it to other pathologies and cells other than hepatocytes.

\section{List of Abbreviations Used}

AI: anemia of inflammation siRNA: small interfering RNA

DPC: dynamic polyconjugate

HAMP: hepcidin antimicrobial peptide

RT-qPCR: reverse transcription quantitative real- time

polymerase chain reaction

FPN: ferroportin

dsDNA: double-stranded RNA

PBAVE: polyvinyl ether

PEG: polyethylene glycol

NAG: N-acetylgalactosamine

ASGPr: asialoglycoprotein receptor

CDM: carboxy dimethylmaleic anhydride

ELISA: enzyme-linked immunosorbent assay

TNF- $\alpha$ : tumour necrosis factor alpha 
UNDERGRADUATE RESEARCH IN NATURAL AND CLINICAL SCIENCE AND TECHNOLOGY (URNCST) JOURNAL Read more URNCST Journal articles and submit your own today at: https://www.urncst.com

IL-6: interleukin-6

IFN- $\alpha$ : interferon alpha

ALT: alanine transaminase

AST: aspartate aminotransferase

\section{Conflicts of Interest}

The authors declare no conflicts of interest.

\section{Ethics Approval and/or Participant Consent}

As no experiment was conducted, ethics approval and participant consent were not needed. However, in the case of an actual study, approval would be sought from Hamilton's Integrated Research Ethics Board of McMaster University. As well, experimental procedures would need to follow the guidelines of the Canadian Council on Animal Care and be approved by the Animal Research Ethics Board of McMaster University.

\section{Authors' Contributions}

IB: Contributed to study design, planned and drafted the manuscript, revised the manuscript, and gave final approval of the version to be published.

GC: Contributed to study design, planned and drafted the manuscript, revised the manuscript, and gave final approval of the version to be published.

CK: Contributed to study design, planned and drafted the manuscript, revised the manuscript, and gave final approval of the version to be published.

JQ: Contributed to study design, planned and drafted the manuscript, revised the manuscript, and gave final approval of the version to be published.

NT: Contributed to study design, planned and drafted the manuscript, revised the manuscript, and gave final approval of the version to be published.

TY: Contributed to study design, planned and drafted the manuscript, revised the manuscript, and gave final approval of the version to be published.

AZ: Contributed to study design, planned and drafted the manuscript, revised the manuscript, and gave final approval of the version to be published.

\section{Acknowledgements}

Figure 1 was created with Biorender.com. Figure 2 was created with Microsoft OneNote.

\section{Funding}

This protocol was not funded.

\section{References}

[1] Abbaspour N, Hurrell R, Kelishadi R. Review on iron and its importance for human health. Journal of Research in Medical Sciences: The Official Journal of Isfahan University of Medical Sciences. 2014 Feb;19(2):164-74. Available from: https://www.ncbi.nlm.nih.gov/pmc/ articles/PMC3999603/

Bae et al. | URNCST Journal (2021): Volume 5, Issue 12 DOI Link: https://doi.org/10.26685/urncst.301
[2] Wallace DF. The regulation of iron absorption and homeostasis. The Clinical Biochemist Reviews. 2016 May;37(2):51-62. Available from: https://www.ncbi .nlm.nih.gov/pmc/articles/PMC5198508/

[3] Nemeth E, Ganz T. The role of hepcidin in iron metabolism. Acta Haematologica. 2009 Nov;122(23):78-86. https://doi.org/10.1159/000243791

[4] Weiss G, Ganz T, Goodnough LT. Anemia of inflammation. Blood. 2019 Jan 3;133(1):40-50. https://doi.org/10.1182/blood-2018-06-856500

[5] Theurl I, Aigner E, Theurl M, Nairz M, Seifert M, Schroll A, Sonnweber T, Eberwein L, Witcher DR, Murphy AT, Wroblewski VJ, Wurz E, Datz C, Weiss G. Regulation of iron homeostasis in anemia of chronic disease and iron deficiency anemia: Diagnostic and therapeutic implications. Blood. 2009 May 21;113(21):5277-86. https://doi.org/10.1182/blood2008-12-195651

[6] Vogt A-CS, Arsiwala T, Mohsen M, Vogel M, Manolova V, Bachmann MF. On iron metabolism and its regulation. International Journal of Molecular Sciences. 2021 Jan;22(9):4591. https://doi.org/10.3390/ ijms22094591

[7] Cronin SJF, Woolf CJ, Weiss G, Penninger JM. The role of iron regulation in immunometabolism and immune-related disease. Frontiers in Molecular Biosciences. 2019;6:116. https://doi.org/10.3389/ fmolb.2019.00116

[8] Theurl I, Mattle V, Seifert M, Mariani M, Marth C, Weiss G. Dysregulated monocyte iron homeostasis and erythropoietin formation in patients with anemia of chronic disease. Blood. 2006 May 15;107(10):4142-8. https://doi.org/10.1182/blood-2005-08-3364

[9] Nemeth E, Ganz T. Anemia of inflammation. hematology/oncology clinics of North America. 2014 Aug;28(4):671-81. https://doi.org/10.1016/j.hoc.2014 .04 .005

[10] Nairz M, Schroll A, Demetz E, Tancevski I, Theurl I, Weiss G. 'Ride on the ferrous wheel' - The cycle of iron in macrophages in health and disease. Immunobiology. 2015 Feb 1;220(2):280-94. https://doi.org/10.1016/j.imbio.2014.09.010

[11] Fraenkel PG. Anemia of inflammation: A review. Medical Clinics of North America. 2017 Mar;101(2): 285-96. https://doi.org/10.1016/j.mcna.2016.09.005

[12] Ganz T. Hepcidin and iron regulation, 10 years later. Blood. 2011 Apr 28;117(17):4425-33. https://doi.org/ 10.1182/blood-2011-01-258467

[13] Dana H, Chalbatani GM, Mahmoodzadeh H, Karimloo R, Rezaiean O, Moradzadeh A, Mehmandoost N, Moazzen F, Mazreah A, Marmari V, Ebrahimi M, Rashno MM, Abadi SJ, Gharagouzlo E. Molecular mechanisms and biological functions of siRNA. International Journal of Biomedical Science. 2017 Jun;13(2):48-57. Available from: https://www.ncbi.nlm .nih.gov/pmc/articles/PMC5542916/ 
UNDERGRADUATE RESEARCH IN NATURAL AND CLINICAL SCIENCE AND TECHNOLOGY (URNCST) JOURNAL Read more URNCST Journal articles and submit your own today at: https://www.urncst.com

[14]Fung E, Nemeth E. Manipulation of the hepcidin pathway for therapeutic purposes. Haematologica. 2013 Nov;98(11):1667-76. https://doi.org/10.3324/ haematol.2013.084624

[15] Sonnweber T, Pizzini A, Tancevski I, Löffler-Ragg J, Weiss G. Anaemia, iron homeostasis and pulmonary hypertension: A review. Internal and Emergency Medicine. 2020 Jun;15(4):573-85. https://doi.org/ 10.1007/s11739-020-02288-1

[16] Sun CC, Vaja V, Babitt JL, Lin HY. Targeting the hepcidin-ferroportin axis to develop new treatment strategies for anemia of chronic disease and anemia of inflammation. American Journal of Hematology. 2012 Apr;87(4):392-400. https://doi.org/10.1002/ajh.23110

[17] Sirlin CB, Reeder SB. Magnetic resonance imaging quantification of liver iron. Magnetic Resonance Imaging Clinics of North America. 2010 Aug;18(3): 359-ix. https://doi.org/10.1016/j.mric.2010.08.014

[18] Rozema DB, Lewis DL, Wakefield DH, Wong SC, Klein JJ, Roesch PL, et al. Dynamic Polyconjugates for targeted in vivo delivery of siRNA to hepatocytes. Proceedings of the National Academy of Sciences. 2007 Aug 7;104(32):12982-7. https://doi.org/10.1073/ pnas.0703778104

[19] Lewis D. Dynamic Polyconjugates (DPC) Technology: An Elegant Solution to the siRNA Delivery Problem [Internet]. Arrowhead Research Corporation. 2011 [cited 2021 Jun 15]. Available from: https://www.semanticscholar.org/paper/DynamicPolyconjugates-(-DPC-)-Technology-\%3A-An-toLewis/ac8a4ba8b65c52e44bbb2cb7ce297c00280146bf \#citing-papers

[20] Wakefield DH, Klein JJ, Wolff JA, Rozema DB. Membrane activity and transfection ability of amphipathic polycations as a function of alkyl group size. Bioconjugate Chemistry. 2005 Sep 1;16(5): 1204-8. https://doi.org/10.1021/bc050067h

[21] Cui H, Zhu X, Li S, Wang P, Fang J. Liver-targeted delivery of oligonucleotides with $\mathrm{N}$ acetylgalactosamine conjugation. American Chemical Society Omega. 2021 Jun 29;6(25):16259-65. https://doi.org/10.1021/acsomega.1c01755

[22] Roberts RA, Ganey PE, Ju C, Kamendulis LM, Rusyn I, Klaunig JE. Role of the Kupffer cell in mediating hepatic toxicity and carcinogenesis. Toxicological Sciences. 2006 Nov 28;96(1):2-15. https://doi.org/10.1093/toxsci/kfl173

[23] Tai W. Current aspects of siRNA bioconjugate for in vitro and in vivo delivery. Molecules. 2019 Jun; 24(12): 2211. https://doi.org/10.3390/molecules24122211

[24] Kim A, Fung E, Parikh SG, Valore EV, Gabayan V, Nemeth E, et al. A mouse model of anemia of inflammation: Complex pathogenesis with partial dependence on hepcidin. Blood. $2014 \mathrm{Feb}$ 20;123(8):1129-36. https://doi.org/10.1182/blood2013-08-521419

Bae et al. | URNCST Journal (2021): Volume 5, Issue 12 DOI Link: https://doi.org/10.26685/urncst.301
[25] Nallagangula KS, Nagaraj SK, Venkataswamy L, Chandrappa M. Liver fibrosis: A compilation on the biomarkers status and their significance during disease progression. Future Science OA. 2017 Oct 5;4(1): FSO250. https://doi.org/10.4155/fsoa-2017-0083

[26] D Wong ML, Medrano JF. Real-time PCR for mRNA quantitation. BioTechniques. 2005 Jul 1;39(1):75-85. https://doi.org/10.2144/05391RV01

[27] Song B, Bian Q, Shao C-H, Liu A-A, Jing W, Liu R, et al. Sox 2 function as a negative regulator to control HAMP expression. Biological Research. 2015 May 6;48(1):23. https://doi.org/10.1186/s40659-015-0013-z

[28] Gulec S, Collins JF. Investigation of iron metabolism in mice expressing a mutant menke's copper transporting ATPase (Atp7a) protein with diminished activity (Brindled; $\mathrm{Mo}^{\mathrm{Br} / \mathrm{y}}$ ). PLOS ONE. 2013 Jun 11;8(6):e66010. https://doi.org/10.1371/journal.pone .0066010

[29] Huggett J, Dheda K, Bustin S, Zumla A. Real-time RTPCR normalisation; Strategies and considerations. Genes \& Immunity. 2005 Jun;6(4):279-84. https://doi.org/10.1038/sj.gene.6364190

[30] Rebouças E de L, Costa JJ do N, Passos MJ, Passos JR de S, Hurk R van den, Silva JRV. Real time PCR and importance of housekeepings genes for normalization and quantification of mRNA expression in different tissues. Brazilian Archives of Biology and Technology. 2013 Feb;56:143-54. https://doi.org/10.1590/S1516$\underline{89132013000100019}$

[31] Young DS, Hicks JM. Method for the automatic determination of serum iron. Journal of Clinical Pathology. 1965 Jan;18(1):98-102. https://doi.org/ $\underline{10.1136 / \text { jcp. } 18.1 .98}$

[32] Duck KA, Connor JR. Iron uptake and transport across physiological barriers. BioMetals. 2016 Aug 1;29(4): 573-91. https://doi.org/10.1007/s10534-016-9952-2

[33] Hu X, Shi Y, Zhang P, Miao M, Zhang T, Jiang B. dMannose: Properties, production, and applications: An overview. Comprehensive Reviews in Food Science and Food Safety. 2016 Jul;15(4):773-85. https://doi.org/10.1111/1541-4337.12211

[34] Vandamme TF. Use of rodents as models of human diseases. Journal of Pharmacy and Bioallied Sciences. 2014;6(1):2-9. https://doi.org/10.4103/0975-7406 .124301

[35] Fischbacher C, Bhopal R, Patel S, White M, Unwin N, Alberti KGMM. Anaemia in Chinese, South Asian, and European populations in Newcastle upon Tyne: Cross sectional study. British Medical Journal. 2001 Apr 21;322(7292):958-9. https://doi.org/10.1136/bmj.322 .7292 .958

[36] Duration of siRNA Induced Silencing: Your Questions Answered - CA [Internet]. [cited 2021 Nov 13]. Available from: www.thermofisher.com/ca/en/home/ references/ambion-tech-support/rnai-sirna/tech-notes/ duration-of-sirna-induced-silencing.html 
UNDERGRADUATE RESEARCH IN NATURAL AND CLINICAL SCIENCE AND TECHNOLOGY (URNCST) JOURNAL

Read more URNCST Journal articles and submit your own today at: https://www.urncst.com

\section{Article Information}

Managing Editor: Jeremy Y. Ng

Peer Reviewers: Siobhan O'Brien, Saameh Siddique

Article Dates: Received Jul 24 21; Accepted Nov 26 21; Published Dec 1021

\section{Citation}

Please cite this article as follows:

Bae IO, Cheung GC, Kim C, Qiu JX, Tasnim N, Yu T, Zhu A. siRNA dynamic polyconjugates for the targeting of hepatocyte HAMP genes as potential treatment for anemia of inflammation: A research protocol. URNCST Journal. 2021 Dec 10: 5(12). https://urncst.com/index.php/urncst/article/view/301

DOI Link: https://doi.org/10.26685/urncst.301

\section{Copyright}

(C) Isabel O. Bae, Grace C. Cheung, Chelsea Kim, Joyce X. Qiu, Najifah Tasnim, Tiffany Yu, Andy Zhu. (2021). Published first in the Undergraduate Research in Natural and Clinical Science and Technology (URNCST) Journal. This is an open access article distributed under the terms of the Creative Commons Attribution License (https://creativecommons.org/licenses/by/4.0/), which permits unrestricted use, distribution, and reproduction in any medium, provided the original work, first published in the Undergraduate Research in Natural and Clinical Science and Technology (URNCST) Journal, is properly cited. The complete bibliographic information, a link to the original publication on http://www.urncst.com, as well as this copyright and license information must be included.

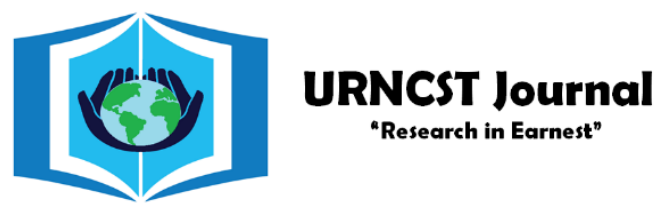

\section{Funded by the Government of Canada}

\section{Canadà̀}

Do you research in earnest? Submit your next undergraduate research article to the URNCST Journal!

| Open Access | Peer-Reviewed | Rapid Turnaround Time | International |

| Broad and Multidisciplinary | Indexed | Innovative | Social Media Promoted |

Pre-submission inquiries? Send us an email at info@ urncst.com | Facebook, Twitter and LinkedIn: @URNCST

Submit YOUR manuscript today at https://www.urncst.com! 